Dr BOJAN B. DIMITRIJEVIĆ, naučni savetnik

Institut za savremenu istoriju

UDK 355.1(497.11)"1916"(093.3)

Beograd, Trg Nikole Pašića 11

94(497.11)"1916"(093.3)

\title{
SRPSKI VOJNIK NA SOLUNSKOM FRONTU 1916-1918*
}

\begin{abstract}
APSTRAKT: U vremenu obeležavanja 100-godišnjice od početka Prvog svetskog rata, u naučnoj javnosti je aktuelizovano bavljenje ovim periodom. Istraživanje se uglavnom usredsredilo na vojno-političke događaje. Uočili smo nedostatak novih istraživanja o samom srpskom vojniku $i$ njegovom životu na frontu, mimo angažovanja u borbi i svakodnevnim vojničkim zaduženjima. Kako izvori prvog reda uglavnom ne posvećuju ovom pitanju previše pažnje, članak je nastao na analizi sekundarnih izvora, mahom sećanja i memoarskih zapisa o životu srpskih vojnika na Solunskom frontu.
\end{abstract}

Ključne reči: Srpska vojska, Solunski front, Saveznici, Solun, moral, predrasude

Srpski vojnik čijim je trudom i požrtvovanjem iznedrena pobeda Srbije u Prvom svetskom ratu bio je i ostao slavljen, ali čini se bez pomnije analize njegovog unutrašnjeg profila i ponašanja tokom boravka na frontu u tri ratne godine: od 1916. do 1918. Boravak van otadžbine, sa neizvesnim ishodom i trajanjem, život u borbi i rovovima, odnosi sa starešinama, susreti sa savezničkim i protivničkim vojnikom, nove navike i ponašanja - sve je to uticalo na stvaranje specifičnog ratnog profila srpskog vojnika. $\mathrm{O}$ ovome u principu ne govore arhivska dokumenta, koja se usredsređuju na borbe na frontu ili druge tipične vojne aktivnosti. O ovom problemu svedoče pojedini memoarski zapisi savremenika. Sredinom 1980-ih u tri knjige autora Dragutina Paunića i Milije Đorđevića sabran je veći broj usmenih izjava tada još uvek živih solunskih boraca, uglavnom iz Šumadije. ${ }^{1}$ Ove izjave po

${ }^{*}$ Rad je deo projekta Konflikti i krize - saradnja i razvoj u Srbiji i regionu u 19. i 20. veku (47030), koji finansira Ministarstvo prosvete, nauke i tehnološkog razvoja Republike Srbije.

${ }^{1}$ Dragutin Paunić, Milija Đorđević, Srbijico, dušo gorka - priče solunaca, Beograd 1988; Isti, Tri sile pritisle Srbijicu, drugo izdanje, Beograd 1988; Dragutin Paunić, Kad su vojske prolazile, ratni dnevnici, Beograd 1988. 
svojoj živosti i okrenutosti svakodnevnom životu i iskušenjima srpskog vojnika u ratovima 1912-1918, bile su inicijator da u jednom članku pokušamo da lociramo sve osobenosti života i ponašanja srpskog vojnika na Solunskom frontu tokom 1916-1918. godine.

\section{Vojnik na liniji fronta}

Jedan od prvih koji je pisao o srpskom vojniku na frontu bio je pisac Dragiša Vasić. I sam rezervni oficir, koji je rat proveo u 10. pešadijskom puku, Vasić upečatljivo konstatuje: „Na Krfu pogled je uvek bio mutan i ostao takav sve dok se nije krenulo na Halkidik. A tome putu radovalo se iskreno..." Pokret i put prema otadžbini postao je tada „jedna jasna misao". ${ }^{2}$ Posle dolaska sa oporavka na Krfu, većina Srpske vojske smatrala je da je boravak na frontu privremen i da će posle serije borbi kroz koje je vojska prošla u drugoj polovini 1916. povratak u otadžbinu pitanje dana. „Samo posle nekoliko dana, međutim, on je doživeo novo razočarenje: on beše verovao da će napasti, a bio je napadnut. On se nadao da će poći napred, a morao se povlačiti..." Zanimljiva je i beleška rezervnog potporučnika Milutina Ristića iz 23. pešadijskog puka o danima na Gorničevskom bojištu 1916: „Dan nas je zatekao u plitkim rovčićima prve borbene linije. Ma koliko da sam nastojao da svoje vojnike nateram da se bolje utvrde i obezbede, nisam u tome uspevao, jer su nalazili izgovor da se o naređenje ogluše. „Do Srbije ima još mnogo i mnogo položaja, pa ako na svakom budemo pravili rovove, kad ćemo do nje stići?" reče jedan. „Ovako je lakše poći napred“, reče drugi“. ${ }^{3}$

Dragiša Vasić navodi da je „na ulazu u otadžbinu, on tako strpljivo očekivao da se pojavi Pravda. A taj optimizam na solunskom frontu bio je mnogima neshvatljiv. Na tome frontu on je uvek izgledao spreman za polazak. On nikad nije hteo da veruje da je to front odbrane. Svako novo pridolaženje trupa davalo mu je krila. Svaka artiljerijska demonstracija za njega je značila ofanzivu. Na pitanje „Šta znače ovi topovski pucnji?“, on je redovno radosno odgovarao: „Počinjemo, u ime Boga“. I posle sviju razočaranja, pri novom bombardovanju, on je to isto odgovarao. On se nadao protiv svake nade...". ${ }^{4}$ Ispostavilo se, međutim, da će srpski vojnik u rovovima Solunskog fronta provesti pune tri ratne sezone. Prvi put, srpski vojnik je tako dugo živeo na linijama fronta. Boravak na frontu nisu bile samo borbe već i dugi dani osmatranja, iščekivanja, svakodnevnog života. Tako je stvoren poseban ambijent na linijama i u pozadini fronta.

${ }^{2}$ Dragiša Vasić, Karakter i mentalitet jednog pokolenja, u: Dragiša Vasić, Odabrana dela, Beograd 1990, 50.

Žika Živulović, Napred u Otadžbinu, Beograd 1989, 65.

${ }^{4}$ D. Vasić, $n$. d., 55-56. 
Kapetan Vladimir Stanojević, lekar 1. jugoslovenskog puka, ovako je opisao odsek Solunskog fronta na koji je stigao maja 1918: „Prolazeći kroz Donji Požar video sam u njemu mnoge pozadinske delove i puno šatora, zemunica, improvizovanih kućica. Penjući se uz brdo, susretao sam na svakom koraku mnoge komordžije i vojnike koji su silazili sa položaja zbog raznih potreba i poslova. U Gornjem Požaru video sam mnogo porušenih kuća i razne zemunice i improvizovane kućice. Iznad sela put je ostavljao iza sebe šumu i peo se uza same gole litice. Pored puta i iznad njega videle su se mnoge zemunice pripijene uz stene kao lastina gnezda. Prošao sam i pored zemunice, na kojoj je bila mala tabla sa natpisom Vila Zora. Puk je bio u rovovima na Kotki. " ${ }^{5}$ Mladi oficir 12. puka, Dragiša Pandurević, na frontu maja 1917. ovako opisuje oficirske smeštaje: „Piju se kave i pišu akta. U susednoj kolibi, koja je od moje odvojena samo retkim talpama, sedi komandant puka i načelnik štaba brigade. Pričaju privatne stvari, puše i skoro veselo ćeretaju. A tamo, dosta daleko, srpski vojnik ukočena pogleda, sa šatorskim krilom na glavi stoji u rovu i čeka mir." ${ }^{6}$

Dragiša Vasić piše: „Onim istim oštrim čukama, što ih je nedavno bio osvojio, vraćao se on posle nekoliko meseci na front... I istog dana on bi zauzimao svoje mesto $u$ rovu. A rov, to je njegovo najmilije boravljenje $u$ izgnanstvu i ni za trunku to nije preterano rečeno. On nije voleo bolnicu, on nije čekao da mu istekne bolovanje, on je uvek ovamo žurio, jer je hteo da je s drugovima i da je bliže, jer je voleo da s položaja gleda u daljinu... i ugodnije sanja o kući." ${ }^{7}$ Vojnici su donekle bili plastičniji i svedeniji na bazična pitanja. Tako vojnik Vitomir Đorđević ovako vidi svoje boravište: „Spavamo u zemunicama. Bukve iscepane na gredice jedna do druge, po gredicama stavili smo suvu paprat i suvu travu, pa prostremo ćebad i legnemo. Imamo šinjele, pokrijemo se. Zimi nasred zemunice zapalimo pomalo vatre. Toplo i zimi. Ručak dobijemo u manjerke, donose nam kuvari po četama... Svaki obrok dobijamo na vreme, i sve dosta i dobro. Dobijamo pasulj, pirinač i po parče mesa. I beo leba." 8

\section{Drugarski odnosi vojnika i starešina}

Duži boravak na frontu stvorio je prisnije odnose između oficira, podoficira i vojnika. Jedan oficir ovako svedoči: „Sloboda u ophođenju vojnika sa oficirima. Nesta one krute discipline po kojoj je vojnik bio mnogo

\footnotetext{
${ }^{5}$ Vladimir Stanojević, Moje ratne beleške i slike, Ljubljana 1934, 187-189.

${ }^{6}$ Mile S. Bjelajac, General Dragiša Pandurović život i svedočenja, Beograd 2007, 103.

${ }^{7}$ D. Vasić, n. d., 53.

${ }^{8}$ Iskaz Vitomira Đorđevića, u: D. Paunić, M. Đorđević, Srbijico, dušo gorka - priče solunaca, 144.
} 
daleko od nas. Sada (vlada) familijarnost neka u ophođenju, kao ranije kod II poziva... Četvorogodišnji rat, zajedničke patnje, muke, opasnosti, zajedničko dobro i zlo, stvorilo je neku rodbinsku vezu među nama. Slobodno se razgovara.“" To primećuju i vojnici: „Mi smo bili toliko prisni, ili smo više nego braća. Izbrisana je u rovu razlika između vojnika i starešine. Bilo je i zabrinutih ljudi, vidi se pritisla ga neka muka, život je takav. “10

Kao posledica dugotrajnosti rata, u pojedinim jedinicama je bio (ostao) samo iskusan vojnički kadar. To je bilo posebno izraženo u 1916, pre nego što će iz Tunisa stići najmlađa godišta regruta ili dobrovoljci sa raznih strana sveta. Tako kada 1916. prima vod u 2. puku, potporučnik Jakov Ljotić piše da u njegovom sastavu ima „42 vojnika, i to tri narednika, šest podnarednika i 33 kaplara. Ni jednog redova u vodu nije bilo." ${ }^{11} \mathrm{U}$ takvoj situaciji sa iskusnim vojnicima i podoficirima, ni oficir nije mogao a da ne razvije odnos poverenja i prijateljstva. Vojnici su takav odnos cenili i nagrađivali ga požrtvovanjem i bezuslovnim izvršavanjem naredbi, čak i u najtežim situacijama.

Nekoliko komandanata i komandira posebno je isticano zbog vojničkih i ljudskih kvaliteta na frontu. Komandant 11. puka Šumadijske divizije, potpukovnik Vojislav Tomić, bio je jedan od komandanata pukova koji je zapamćen kao neko koji je sve tri ratne godine proveo „na 50 metara od prve linije“. Takve komandante vojska je posebno volela, jer su sa njom delili i dobro i zlo. „Bio je sposoban čovek, opasan čovek bio! Ništa nema da oskuđevaš: nek' ti se iscepaju pantalone, bluza, odma' piši trebovanje, novo ima da dobiješ. Bio je ljut čovek: kocka ne sme da bude, laža ne sme da bude. Ako vam ne valja, imate bugarsku, imate nemačku vojsku, izvolite. Ali ako vas ja uvatim, ja ću da vam sudim: pištolj za vrat. Disciplinu zaveo. I za oficire bio opasan. Vojska ga volela i poštovala." Ovaj komandant je svoju jedinicu držao bez smene na istom odseku fronta dve godine. ${ }^{12}$

O još jednom takvom starešini kapetanu Dimitriju Đ. Tošiću, ostavio je upečatljivo sećanje njegov vodnik, potporučnik Ljotić: „Bio je pravi starešina - domaćin. Vodio je računa o svakoj sitnici, o svakom vojniku, motrio na sve, kontrolisao rad i izvršenje svakog naređenja. Svi su znali da on bdi, da misli o svemu, da njegovo oko sve vidi i svi su se starali da u potpunosti izvrše svoju dužnost. Njegova četa imala je svakoga dana tri jela za ručak, odvojeno supa, odvojeno meso, odvojen pirinač, makarone ili krompir.

\footnotetext{
${ }^{9}$ Golgota i vaskrs Srbije 1915-1918, prir. Silvija Đurić, Vidosav Stevanović, drugo izdanje, Beograd 1989, 526.

${ }^{10}$ Iskaz Desimira Milenovića, u: Srbijico, dušo gorka - priče solunaca, 243.

${ }^{11} \mathrm{~J}$. V. Ljotić, Služba u vojsci i učešće u ratovima, Minhen 1967, 147.

${ }^{12}$ Iskaz Vitomira Đorđevića, u: Srbijico, dušo gorka - priče solunaca, 141-142; Iskaz Aleksandra Jankovića, u: Srbijico, dušo gorka - priče solunaca, 223.
} 
I sve je moralo biti najukusnije spravljeno. Ostale čete imale su od istog materijala samo jedno jelo, gde je sve zajedno bilo pomešano. Svaki vojnik u Tošićevoj četi imao je prišiven svoj broj na vešu, pa se veš prao kod kujne zajednički i svake subote delio čist veš vojnicima. Njegova četa imala je svog krojača, koji je postepeno prepravljao odelo vojnicima, tako da su svi vojnici izgledali i bili obučeni kao podoficirska škola. Svaki njegov desetar morao je da vodi brigu o svojoj desetini, vodnik o vodu, četni narednik o administraciji, o kuvarima i komordžijama. Kapetan Tošić nije pio, nije se kockao, nije voleo prazne razgovore. Ili je čitao, ili je razmišljao šta da uradi za svoju četu. Obraćao je pažnju da vojnici nikad ne budu sami. Podoficiri i vodnici morali su se uvek naći oko vojnika, kako bi se običnim razgovorima i ličnim dodirom bolje upoznali, poučili i zabavili. Jednom rečju, četa kapetana Tošića bila je jedna velika porodica, u kojoj je vršenje dužnosti bila sveta, a u isto vreme najlakša obaveza, koja se postizala jedino brigom o vojnicima, prijateljskim razgovorima i ljubavlju prema svakom vojniku. Tek kad smo stigli na front, kad su borbe otpočele, ja sam video šta znači ovako ophođenje sa vojnicima i ovako upravljanje četom, i kako su vojnici samo na jednu reč, ili čak i samo na jedan pogled svojih starešina izvršavali naređenja skopčana i sa životnom opasnošću. “13

Ističući prisan odnos starešine i vojnika, u svojim sećanjima divizijski general Milorad Radović ovako opisuje svog komandira mitraljeskog odeljenja, mladog potporučnika Dragoljuba Dražu Mihailovića „koji je padao u oči jer je nosio naočare koje su se tada među mladim oficirima nisu viđale“. Draža se „za vreme puta malo družio sa oficirima. Njegovo društvo bili su njegovi vojnici i podoficiri sa kojima je još od mobilizacije i početka rata. Iz razgovora i čestih pošalica među njima, osećala se ona intimnost koja je vezivala starešine i vojnike u dugom zajedničkom službovanju i ratnim nevoljama." 14

Običan vojnik je sa neskrivenim zadovoljstvom primećivao kada bi ko od najviših komandanata bio uz njih na linijama fronta. U sećanjima na dane provedene na Solunskom frontu, pojava najviših vojnih rukovodilaca ili predstavnika kraljevske kuće bila je uvek zapažena. Vojnička percepcija najviših rukovodilaca vojske i Kraljevine uvek je bila pozitivna. Ovo nam takođe služi kao jedan od parametara za sagledavanje same Srpske vojske i odnosa u njoj.

Srpski vladari - kralj Petar I ili regent Aleksandar, bili su među vojskom na frontu još od prvih dana rata. Tako je bilo i na Solunskom frontu. Njihov dolazak u bolnice, obilazak linija fronta ili samo susretanje bili su

${ }^{13}$ J. V. Ljotić, $n$. d., 166.

${ }^{14}$ Milorad. R. Radović, Draža Mihailović na Solunskom frontu. Iz knjige U slavu Draže Mihailovića, preneseno u listu „Pogledi“ 15. juna 1990, 28-30. 
događaji koje je svako od vojnika ili oficira posebno pamtio. Tako Jakov Ljotić 1916, sedi za slavskom trpezom u svom 2. puku sa regentom Aleksandrom i portretiše ga na sledeći način: „Prestolonaslednik je vrlo malo jeo i pio, a vrlo mnogo pušio. Razgovarao je sve vreme sa prisutnima i bio je vrlo dobro raspoložen“". ${ }^{15}$ Vojnici su posebno merili njegovo poistovećenje sa vojničkim zadacima i uslovima na frontu. „Kralj Aleksandar obuko vojnički šinjel. I on, i onaj oficir sa njim, da se ne vidi da je kralj, da se ne izlaže opasnosti. I vojničku kapu nosi, nije ni šapku sa grbom i zlatnim širitom nosio ko što smo ga videli kad smo bili u pozadini. Naočari uvek nosio. Mi znamo da je kralj, nas pripremili komandiri, da budemo ispravni da pozdravimo. Govori nam, kao i svaki komandir, da se držimo, hrabri nas."16 Regent Aleksandar je obilazio i ranjene vojnike u bolnicama u Solunu. Neke, teško ranjene, na licu mesta je i odlikovao. ${ }^{17}$ Regentovi dolasci među vojnike na frontu su ga učinili omiljenim, iako je Solunska afera 1917. u principu mogla da nanese štetu njegovom ugledu. Jedan vojnik kaže za regenta: „Toliko nas je čuvao on, naš vrhovni komandant, mi smo bili zadovoljni sa njim, pa makar svi izginuli“". ${ }^{18}$

Kralj Petar I, iako se povukao sa prestola 1914. godine, bio je tokom rata prisutan među vojskom. Bio je zašao u godine, ali je svojim prisustvom i deljenjem sudbine sa narodom i vojskom, posebno tokom povlačenja 1915, privlačio pažnju i emocije posmatrača. Iako je tada imao više od 70 godina, zadržao je vojničko držanje i navike. U sećanjima obično mu je dodavan pridev „matori“. On je boravio u pozadini fronta tokom 1916 (u Solunu, odnosno u mestima Aedipso i Halkis), a kasnije u jednoj solunskoj vili, i uglavnom se nije viđao na linijama fronta. Po gradu i okolini je išao samo privatnim poslom. Jedno vreme je za njegov prevoz korišćen motocikl sa prikolicom. „Niko naš motocikl nije pratio. Kralj je bio obučen u generalsku uniformu, nikakve naočari nisam stavljao. Ni ja, ni Kralj." Njegov vozač se dičio činjenicom da vozi kralja. „Bio je dobar čovek, nikad nije ljut, osoran ni strog. Uvek je voleo da razgovara. " ${ }^{19}$ Posebnu pažnju je privlačio princ Đorđe. On je viđan u Solunu. Njegove reakcije i oštar odnos prema vojnicima koje bi susreo, činile su da vojska zazire od njega. „Bio je princ Đorđe, onako, nekako... nervozan". ${ }^{20}$

Vojvoda Mišić i vojvoda Stepanović kao najpoznatiji i po činu najstariji srpski komandanti najviše su privlačili pažnju. Vojnik dodeljen da

\footnotetext{
${ }^{15}$ J. V. Ljotić, $n$. d., 153

${ }^{16}$ Iskaz Milutina Ristića, u: Srbijico, dušo gorka - priče solunaca, 131.

${ }^{17}$ Iskaz Vitomira Đorđevića, u: Srbijico, dušo gorka - priče solunaca, 153.

${ }^{18}$ Iskaz Radosava Markovića, u: D. Paunić, M. Đorđević, Tri sile pritisle Srbijicu, 139.

${ }^{19}$ Iskaz Svetislava Kovačevića, u: Srbijico, dušo gorka - priče solunaca, 310.

${ }^{20}$ Iskaz Vitomira Đorđevića, u: Srbijico, dušo gorka - priče solunaca,153.
} 
bude posilni vojvodi Mišiću svedoči: „Šes' meseci nije leg'o u krevet da spava, nego se navali na ruku i spava na stolu“. Mišićev radni sto je asketski „nema ničega kod njega, samo mape, akta, telefon i svetli lampa njegova... Obično zamišljen bio...". ${ }^{21}$ Vojvoda Mišić je, prema svim sećanjima, bio omiljen i kako kaže jedan vojnik: „Najveći ugled uživao je kod vojnika. Žuća, njega su tako zvali, volela ga vojska“. ${ }^{22}$ Drugi, pak, ovako vidi komandanta 2. armije Stepanovića: „Stepu sam viđ'o, bio komandant Druge armije. Dolazio i kaže: „Braćo, ne bojte se ništa. Neće dugo da se bavimo, biće naše carstvo." On je na konju dolazio, bio u vojvodskom odelu, a idu s njim samo dvojica." ${ }^{23}$ Za vojvodu Stepanovića ostale su i priče da se prerušen u seljaka povremeno kretao po terenu, da ustanovi raspoloženje vojske. ${ }^{24}$

\section{Moral srpskog vojnika}

Na frontu su svi patili za domom i porodicama. I oficiri i vojnici. Mladi oficir Dragiša Pandurović beleži u svoj dnevnik 26. oktobra 1917: „Kuća! Kuća, dom svoj, porodica svoja je meta naših želja, predmet naših maštanja, ideal i idol naš! “25 Dragiša Vasić ukazuje na osobenost odvojenosti srpskih vojnika od svojih najbližih - porodice. „Tamo, jedna ga je briga uvek naročito rastrzala. To je briga o časti njegove porodice." Ovaj pažljivi promatrač svojih vojnika ističe da se pre balkanskih i Svetskog rata za „najveću porodičnu tragediju“ smatrala „umrljana čast, osramoćeni obraz porodice“. Rat je doneo odvajanje od kuće i porodice. Ali Vasić ukazuje: „Rat je odvajanje zdravih, koji se bore, od nezdravih, koji ostaju u kući... jer dok su najbolji van zemlje i udruženi, dotle su najgori u zemlji i bez takmaca. Ovi drugi, to su nakaze što se u miru stidljivo povlače i što su u ratu hrabri samo prema nezaštićenima“. Srbi su „bili još nesrećniji sa svojim spoljašnjim neprijateljima, kojima su nedostajala njihova osećanja o časti porodice. U jesen 1914. izgoneći neprijatelja iz zemlje, oni behu poznali najljuću ranu... Oni koji su doživeli sramotu, nisu mogli više naći smisao požrtvovanja koje se od njih tražilo, a oni koji su bili pošteđeni, strahovaše za budućnost.“ „Briga o časti porodice beše njihova najgorčija briga u izgnanstvu. Iako im je smrt njihovih u ropstvu razdirala srce, oni su je uvek pretpostavljali sramoti“ - ističe Vasić. ${ }^{26}$

Vojska je povremeno imala i zvanične ceremonije, koje su bile značajna demonstracija pripadnosti kolektivu i jačanja morala. Njih je posebno

\footnotetext{
${ }^{21}$ Iskaz Petronija Markovića, u: Srbijico, dušo gorka-priče solunaca, 74.

${ }^{22}$ Iskaz Živadina Čokića, u: Tri sile pritisle Srbijicu, 167.

${ }^{23}$ Iskaz Vitomira Đorđevića, u: Srbijico, dušo gorka - priče solunaca, 145.

${ }^{24}$ Iskaz Radosava Markovića, u: Tri sile pritisle Srbijicu, 138.

${ }^{25}$ M. Bjelajac, n. d., 105.

${ }^{26}$ D. Vasić, $n$.d., 54.
} 
bilo u 1916. godini. Posle obuke, vršena je ponekad smotra celog puka. Evo kako je vidi J. Ljotić: „Za mene je bio nezaboravan trenutak, kada se postroji ceo puk, tri bataljona, sa tri mitraljeska odeljenja, pa se prvo sačeka komandant puka, kome komandant bataljona izlaze u galopu na raport, zatim pred svakim bataljonom odjekuje „Pomozi Bog" i „Bog ti pomogao“, pa onda komanduje pukom i odaje pozdrav zastavi koja se donosi. Potom dolazi molitva, zatim „kape skini“ pa muzika nastavi „Pričesan“, 2.500 ljudi, kao jedan čovek, stoji u stavu mirno, svi šapuću molitvu i svi osećaju jedan retko veliki trenutak. Ne znam da li je u kojoj drugoj vojsci, sem verovatno u carsko-ruskoj, taj trenutak tako veliki, pobožan i uzbudljiv. Posmatrao sam strance, naročito Francuze, koji su bili prisutni i pratili ovu našu svečanost, koliko su bili stvarno impresionirani njom." ${ }^{27}$

Pukovske slave bile su te godine posebno značajne, jer je trebalo srpsku vojsku staviti na noge i napraviti od nje kompaktnu ratnu mašinu. Pre ceremonija, uvežbavane su strojeve radnje i ukrašavani logori. Slavi 2. puka na Krfu 1916. godine prisustvovale su odabrane zvanice: srpski vojni i politički vrh, predstavnici francuske i britanske vojske. „Slava je bila pripremljena da bi se strancima prikazala naša vojska, jer je to bila prva prilika, a nas da oni vide $u$ novim uniformama, sa novim oružjem a starim srcem. "28

I vojnici su na prigodan način obeležavali krsnu slavu. Srpski vojnik je slavio svoju slavu na liniji fronta skromno, sa onim što je oko sebe imao. „Uzmemo 'leba ceo, pa ga presečemo u krst kao slavski kolač, zalijemo vinom, prelomimo, krstimo se. Nabavimo vino, nađemo i zapalimo sveću. Nađe se ribe ili mesa, uz vino. Zajednički ručamo. “29 To je bila specifična manifestacija duhovne veze sa napuštenom kućom i porodicom.

Pred polazak $\mathrm{u}$ boj ili pred ukrcavanje na brod za plovidbu morem obavljana je molitva. „Ceo puk se krsti kad hoćemo u borbu, oficir ni narede. ${ }^{30}$ Vojnici-dobrovoljci (posebno katolici) koji su došli iz Amerike kao da su bili svesniji molitve: „Gledao sam vojnika, koji u rovu, na osmatračnici, naslonjen na grudobran, kraj puške, čita Sveto Pismo (Molitvenik), pogledajući s vremena na vreme i na neprijateljsku stranu. “31

Neki vojnici su se uzdali u molitve ili su imali svoje rituale pred boj. Pojedini su opet isticali: „Ne treba se mnogo uzdati u Boga. Pomeni ga i prekrsti se, ali se uzdaj najviše u sebe“. ${ }^{32}$

27 J. V. Ljotić, $n$. d., 157-158.

${ }^{28}$ Isto, 153.

${ }^{29}$ Iskaz Milutina Ristića, u: Srbijico, dušo gorka - priče solunaca, 128.

${ }^{30}$ Iskaz Milutina Matejića, u: Tri sile pritisle Srbijicu,182.

31 Živan Petrović pešadijski potpukovnik, Podoficiri naše vojske, drugo i prerađeno izdanje, Beograd 1938, 121.

${ }^{32}$ Iskaz Živadina Čokića, u: Tri sile pritisle Srbijicu, 166. 
Iako je pridavana pažnja duhovnoj komponenti života vojnika, uočavaju se tragovi sujeverja kome su rat i ratne situacije posebno pogodovale. $\mathrm{O}$ ovome su ostale kasnije izjave pojedinih vojnika, ili opisi u književnim delima posle rata. Stanislav Krakov piše da leta 1916, u pauzi između borbi „u sumraku vojnici lutaju između žbunja i traže tisovinu, drvo crveno kao višnja, za koje veruju da je sveto, i režu od nje krstiće. To su amajlije koje treba da štite od čelika. Ova masovna pogibija koja nas već pet dana i pet noći prati, pojačala je sujeverje i mistiku ovih planinaca, koji u raznim znacima prirode traže da saznaju svoju sudbinu“. ${ }^{33}$

Neki od vojnika nosili su amajlije. Jedan vojnik 7. puka rodom iz sela Međulužja kod Mladenovca, svedoči: „Kad sam polazio u rat, majka mi u pojas, u kanice, zašila amajliju. Nije mi rekla da je ušila, ali sam vid'o... I ja sam stalno nosio taj pojas, odneo i vratio u Međulužje. Kad je na Krfu bacano na gomilu staro odelo, ja sam pojas savio u klupče, stego u pesnicu i preneo“. ${ }^{34}$ Drugi, pak, rodom od Velike Plane navodi da mu je majka ušila „u tkanice amajliju: od kopile kočicu i pobeg-zrno, od kukuruz, ono što ispod vodenički kamen pobegne nesamleveno. „To će te spasi“, kaže majka sinu: „kuršum ne vaća“. ${ }^{55}$ Trećem vojniku iz okoline Topole, majka je takođe ušila amajliju u kanice. „Ne znam šta je ušila, tamjan samo znam da bio." Ovom vojniku majka je ušila i dukat i nekoliko srebrnih novčića, „kao da su znali šta će da me snađe". ${ }^{36}$

Strah je postojao među srpskim vojnicima, ali o tome nema previše iskaza. Uočava se strah za sopstveni život na frontu, ali i strah od putovanja brodom preko mora, na koji se nadovezivao strah od "sumarena" odnosno potapanja lađe.

Dugotrajnost boravka na frontu je učinila da strah za sopstveni život $\mathrm{u}$ borbi ostane $\mathrm{u}$, reklo bi se, kontrolisanoj meri, pogotovo posle 1916 . godine. Ipak, „bilo je strašljivih ljudi, i kad polazi na stražu i u borbu, drhti, zaklanja se, ne gleda gde puca, puca preko glave, bilo je raznih ljudi."37 Pojedina svedočenja najmlađih regrutnih godišta (1896) govore da je straha, makar iz perspektive tih najmlađih vojnika, bilo: „Kad treba na juriš, svaki vojnik požuteo, svaki drkće ko prut, svaki prebledeo. Molimo se Bogu pred juriš, pred smrt. Pripremamo se za juriš....". ${ }^{38}$ Većina vojnika je mislila da „koji god se vojnik plaši borbe, taj gine. Obavezno“. Loš predosećaj je često istican kao znak nesreće. S druge strane „ima opet slučaj kad čovek neće da pogine, pa nek bije onaj koliko god oće otud, samo ako imaš

\footnotetext{
${ }^{33}$ Stanislav Krakov, Život čoveka na Balkanu, Beograd 1997.175.

${ }^{34}$ Iskaz Vladimira Uroševića, u: Srbijico, dušo gorka - priče solunaca, 183

${ }^{35}$ Iskaz Janićija Zdravkovića, u: Srbijico, dušo gorka - priče solunaca, 196.

${ }^{36}$ Iskaz Branka Čolića, u: Srbijico, dušo gorka - priče solunaca, 263.

${ }^{37}$ Iskaz Aleksandra Jankovića, u: Srbijico, dušo gorka - priče solunaca, 233.

${ }^{38}$ Iskaz Živote Todorovića, u: Srbijico, dušo gorka - priče solunaca, 258.
} 
veka“. ${ }^{39}$ Jedan solunac upečatljivo navodi: „Mi smo vrdnuli sa onog mesta dvaes-trijes metara, slučajno, reko Bog, taman smo mi vrdnuli, a ono granata! ... Da nismo mrdnuli, ni jedan ne bi mrdnuo". ${ }^{40}$

Srpski vojnici su nerado putovali brodom. Strah i nelagodnost u novoj i nepoznatoj sredini izazivali su taj osećaj. Takva putovanja, međutim, bila su neizbežna u 1916. godini. Brodovima se prvo prebacivalo sa albanske obale do Krfa („Tu sam se ja zarek'o: nogom u lađu više nikad!““41), odnosno do Tunisa - za one koji su bili u težem stanju ili tek regrutovani. Potom, kasnije sa Krfa morem, oko Peloponeza sve do Soluna u proleće 1916. I konačno, kada bi ranjenici ili bolesni odlazili na lečenje ili oporavak preko mora u Tunis. Najčešće, ukoliko bi ranjenik bio svestan, on je više voleo da ostane u bolnici u Solunu, uz front. („Neće da ide ni jedan! Ma nijedan! A svi su radi. Neće, zato što stižu davljenici... Ne sme preko mora“" ${ }^{2}$ ) Jedan od uzroka straha bilo je i sveopšte neznanje plivanja među vojnicima, uočeno još u borbama septembra 1914. pri prelasku Save. Na ovo se nadovezivao strah od potapanja, „topljenja“, na moru. Kada se uoči da su srpski vojnici bili neplivači, strah od „sumarena“ i potapanja bio je priličan problem dok se ne bi stiglo do kopna. („'De da skačem ja, kad nisam gazio ni potok do kolena! “43, pita se vojnik 11. puka na lađi koja se vraća na front). Potom, uočljiv je strah od višednevne vožnje brodom preko mora, i nenaviknutost na boravak na brodu, nepreglednost mora, dugotrajnu odvojenost od kopna („Nigde obalu nisam vid'o, samo voda, gde god pogledaš" odnosno drugi koji kaže: „Pitamo jedan drugog: Jesi l' ti ugledao kraj mora? Kaže, nisam, more je veliko, ne može da se vidi kraj. “44).

U specifičnoj duhovnoj klimi iz koje su potekli tadašnji srpski vojnici smatralo se da se treba uzdržavati pljačke, ali i štednje novca. Takođe, treba izbegavati namerno nišanjenje u protivnika, ,jer to su mi govorili stariji vojnici: kad ga nišaniš, nećeš dobro da prođeš."

Najveći porok u Srpskoj vojsci na Solunskom frontu, sudeći prema svim svedočanstvima, bila je kocka koja nije mimoilazila ni oficire i podoficire, niti vojnike. Tada, kada su svi bili na istoj liniji, kocka koja je na početku rata više bila prisutna među aktivnim vojnim licima, proširila se i među vojnicima. Činjenica da je vojska dobijala platu, ma kako bila mala, koja

${ }^{39}$ Iskaz Aleksandra Karića, u: Srbijico, dušo gorka - priče solunaca, 289.

${ }^{40}$ Iskaz Ljubomira Batnića, u: Tri sile pritisle Srbijicu, 12, 67.

${ }^{41}$ Iskaz Dragoljuba Radojkovića u: u: Srbijico, dušo gorka - priče solunaca, 87.

${ }^{42}$ Iskaz Petronija Markovića, u: Srbijico, dušo gorka - priče solunaca, 77.

${ }^{43}$ Iskaz Vitomira Đorđevića, u: Srbijico, dušo gorka - priče solunaca, 155.

${ }^{44}$ Iskaz Živojina Jovanovića, u: Srbijico, dušo gorka - priče solunaca, 170; Iskaz Mihaila Milojevića, u: Tri sile pritisle Srbijicu, 268.

${ }^{45}$ Iskaz Milutina Matejića, u: Tri sile pritisle Srbijicu, 183. 
nije imala gde da se potroši pogodovala je razvoju kocke među vojskom. ${ }^{46}$ („U rovu imalo kocke, igrali vojnici karte“47 „Kartali smo se i u pare“48). Jedan od vojnika, koji za sebe navodi da nije igrao karte, duhovito primećuje: „Mnogo se igralo karte - u pare, samo da ne vidi komandir. Krili se vojnici od oficira. I oficiri su igrali, pa se oni krili od vojnika..." ${ }^{49}$ Milorad Marković ukazuje na pojavu „omalovažavanja novca“ odnosno „kartanja u velike sume, rasipanja u varošima. Čak i francuska komanda skrenula pažnju našoj Vrhovnoj komandi na kako se bezumno baca novac. Rasipao sam novac na Krfu i Solunu na hiljade“. ${ }^{50}$

Alkohol je smatran porokom, ali je prema njemu postojalo više tolerancije. Bilo je vojnika koji su se držali podalje od ovog poroka. Nekima su to stariji govorili pre polaska u rat, neki su sami otkrili štetnost alkohola kada je front pokazao zahteve za visoku trezvenost i ozbiljnost. „Eto, moj komandir iz Šatornje uvek je imao pljosku rakije, srkne i ponudi vojnika. I na koti deset-pedeset iz neopreznosti pogibe“. Uočavano je da piće šteti i protivnicima - Bugarima: „Kad smo uzeli njine rovove, na svakih pet metara petačka stoji, bugarska rakija. Vojski daj rakije, i posle je jebi kako hoćeš. “51

\section{Odnos prema saveznicima}

Od vremena dočeka Srpske vojske na albanskoj obali pa do kraja rata vojnici su razvili poseban odnos prema francuskoj vojsci i Francuzima. Taj više nego prijateljski odnos može da se sažme u prosto vojničko sećanje: „Mi smo voleli Francuze oni su nas spasli“. ${ }^{52}$ Spasavanje vojske na albanskim obalama, evakuacija, slanje u bolnice, oblačenje i opremanje srpskih vojnika - sve je to stvaralo snažan pozitivan utisak o Francuskoj, Francuzima i njihovoj vojsci, koji su delili srpski vojnici („Mnogo su lepo sa nama, Francuzi, onakog naroda nema nigde“"53).

Završetak mučnog perioda posle povlačenja do albanske obale bio je posebno pojačan odnosom Francuza koji su dočekali iscrpljenu srpsku vojsku. Evo upečatljivog svedočenja o tome: „Francuzi... ja dotle nisam vido Francuze. N'umem da vi opišem kaki su ti ljudi. Pazi sad: mi smo dronjavi i vašljivi, ima i' koji su bolesni, a Francuzu to ništa: šiša te, kupa te, oblači te.

\footnotetext{
${ }^{46}$ Iskaz Branka Čolića, u: Srbijico, dušo gorka - priče solunaca, 277.

${ }^{47}$ Iskaz Dragoljuba Radojkovića, u: Srbijico, dušo gorka - priče solunaca, 93.

${ }^{48}$ Iskaz Mijaila Rakića, u: Srbijico, dušo gorka - priče solunaca, 107.

${ }^{49}$ Iskaz Milutina Ristića, u: Srbijico, dušo gorka - priče solunaca, 130.

${ }^{50}$ Golgota i vaskrs Srbije 1915-1918, 523-524

${ }^{51}$ Iskaz Živote Pantića, u: Tri sile pritisle Srbijicu, 155-158.

${ }^{52}$ Iskaz Dragoljuba Mijatovića, u: Srbijico, dušo gorka - priče solunaca, 45.

${ }^{53}$ Iskaz Branka Čolića, u: Srbijico, dušo gorka - priče solunaca, 270.
} 
Sve nam Francuzi dali na predovoljstvo; da jedeš, da poje'š. Obukli me, milina da se pogledaš: novo sve od cokule do kape. Tu doktori njini, komisije, tu kuvari, bolničari... Oživesmo mi. Oni bi vojniku dušu dali. Bog da živi Francuze!" ${ }^{54}$ O Francuzima kao jedinim spasiocima posle albanske golgote svedoče mnogi: „O Francuzima sam na frontu mislio kao o rođenoj braći. Francuzi su svuda bili sa nama. Bolje sloge ne može da bude. Oni su jedini bili naši spasioci. Sve što je bilo potrebno oni su dali od srca" ${ }^{55}$

Već na Krfu, u toku preoružanja i preoblačenja većine preživelog sastava Srpske vojske, vojnici počinju da upoređuju: francuske plave uniforme zamenile su dotadašnje srpske, odnosno ono što je od njih ostalo na putu da mora. „Dobili smo, plave kao nebo, francuske uniforme i lebel puške produžene bajonetom, trouglim i dugim kao ražanj. Postajemo opet vojska". ${ }^{56}$

Posebna novost bilo je uvođenje šlemova. Do tada srpski vojnik nosi francuski šlem tipa „Adrijan“. Na njega se vojska privikavala do dolaska na front, a tamo su već u prvim borbama uočene prednosti šlema, koje su bili od životne važnosti: „Ovi šlemovi spasili su život nekolicini pešaka: udari o šlem i odskoči, ili, ako probije, malo rani. “57 U borbama sa Bugarima, po noći, u dimu ili magli, šlem je bio znak raspoznavanja.

Srpski vojnik je upoređivao i procenjivao dobijeno francusko oružje. Srpske petometke sistema Mauzer i druge donete puške zamenjene su na Krfu francuskim standardnim puškama sa tri metka („trometke“ ili „trojke"). Ove puške se nisu previše volele, jer su one koje su ranije korišćene bile bolje. Francuski puškomitraljezi tipa Šoša bili su posebna novost za Srpsku vojsku i za njih je početkom 1917. organizovana posebna obuka vojnika. „On je težak devet i po kila. Imali su šaržere kao polumesec, dvajes’ pet metaka u šaržeru. Imao sam i pomoćnika, dodavača municije. Jednog ili dva, kako kad. " 58 Francuski mitraljezi tipa Sent Etjen nisu imali sistem hlađenja kao ranije korišćeni Maksimi: „Sent Detjenu“ nije trebalo hlađenje, njegovo je hladnjak od mesinga, a mi smo imali „maksim“. ${ }^{59}$ Takođe, poljski topovi kalibra $75 \mathrm{~mm}$ ili bombe bili su predmet upoređenja. „Bombe su francuske ef-jedan i o-ef, defanzivne i ofanzivne, sve vrste. "60 $U$ avgustu 1916, stižu nove engleske bombe „okrugle kao lopta, koje se pale kao šibice.

\footnotetext{
${ }^{54}$ Iskaz Dragoljuba Radojkovića, u: Srbijico, dušo gorka - priče solunaca, 87.

${ }^{55}$ Iskaz Danila Maslaća, u: Srbijico, dušo gorka - priče solunaca, 121.

${ }^{56}$ S. Krakov, n. d., 152.

${ }^{57}$ Golgota i vaskrs Srbije 1915-1918, 532.

${ }^{58}$ Iskaz Danila Maslaća, u: Srbijico, dušo gorka - priče solunaca, 121; Iskaz Milutina Ristića, u: Srbijico, dušo gorka -priče solunaca, 128.

${ }^{59}$ Iskaz Živadina Čokića, u: Tri sile pritisle Srbijicu, 164; Iskaz Milutina Matejić, u:

${ }^{60}$ Iskaz Vitomira Đorđevića, u: Srbijico, dušo gorka - priče solunaca, 146.
} Tri sile pritisle Srbijicu, 177. 
Svako od nas ima daščicu, koju privezuje na rukav i o nju se trlja upaljač bombe". 61

Boraveći i ratujući na Solunskom frontu, srpski vojnik je prvi put mogao da napravi paralelu sa drugim saveznicima i da ih uporedi, da svoje kvalitete i mane suprotstavi onom što je video na licu mesta. I u ovakvoj analizi Francuzi su dobijali pohvalne ocene: „Francuze mnogo cenim, mnogo. Jer evo što: bio sam sa njima u ratu i po bolnicama, i nigde nisam naišao na lošeg Francuza. Svaki mi priđe kad mu dobacim neku reč, pozdravi se, i odma vadi kutiju, nudi mi cigare. Dok Englezi, to su isto naši saveznici, ja ne bi nikad s njima se složio. On je u stanju da sedi s tobom, a da ne razgovara ništa, da ćuti. Ondak izvadi kutiju, zapali cigaru i ostavi kutiju. Ne nudi. “62 Razlika između saveznika uočena kod mnogih vojnika najlakše se prepoznavala u rečenici „Sa Francuzima smo jeli isti hleb, dok su se Englezi držali po strani" ${ }^{63} \mathrm{O}$ ovome piše i tada mladi podoficir Aleksandar Deroko: „Srbi su se najtešnje družili sa Francuzima. Mi podoficiri sa francuskim podoficirima“. ${ }^{64}$

Oficiri su bili nešto kritičniji prema Francuzima, a to je mogla da bude i posledica naknadnog promišljanja iskustava sa fronta. Prema oceni oficira 2. puka, potporučnika Jakova Ljotića: „Pored Srba, samo su donekle Francuzi, na ovom frontu ratovali, ali vodeći računa da što manje žrtava imaju. Englezi su bili potpuno neaktivni na krajnjem desnom krilu Solunskog fronta i jedina korist od njih je bila da su posedali jedan veliki odsek fronta, koji bi bez njih morali drugi da posednu. Doduše, njihovo prisustvo značilo je mnogo $\mathrm{u}$ čisto moralnom pogledu, kako za nas pozitivno, tako i za Bugare negativno. To isto važi i za Italijane. Ruske dve brigade su se borile, i nisu žalile sebe, ali su bile vrlo male brojem, da bi mogle stvarno da pomognu. “65 Ljotić navodi i slučajeve francuskog držanja na frontu: „Francuzi u našoj eskadrili vršili su svoju službu uredno, ali izbegavajući da se angažuju, kao što bi verovatno činili da su u sastavu svoje vojske, i na frontu u svojoj zemlji. Većina od njih prikrivala je ovakav stav, kamuflirajući ga prividnom revnošću, dok je potporučnik Diran, rodom iz Marselja, otvoreno govorio, „da on ne želi da ostavi svoju glavu na Kajmakčalanu“, dok su svi ostali isto mislili, samo to nisu govorili. I zato su se tražili izgovori da se što manje leti... Isto tako, da se što manje preleću neprijateljske linije fronta, i da se leti nad teritorijom koju neprijatelj drži. Pojedini francuski piloti nisu nikako hteli da pređu liniju fronta." 66

\footnotetext{
${ }^{61}$ S. Krakov, n. d., 170-171.

${ }^{62}$ Iskaz Branka Čolića, u: Srbijico, dušo gorka - priče solunaca, 271.

${ }^{63}$ Iskaz Jovana Carića, u: Tri sile pritisle Srbijicu, 312-313.

${ }^{64}$ Aleksandar Deroko, A ondak je letijo jeroplan nad Beogradom, Beograd 1983, 99.

${ }^{65} \mathrm{~J}$. V. Ljotić, $n$. d., 222.

${ }^{66}$ Isto, 265.
} 
Isti oficir pravi razlike među saveznicima i u solunskim kafanama: „Francuzi su se odlikovali neozbiljnošću, Englezi ozbiljnošću i mnogim trošenjem jakih pića. Rusi prosipanjem para i bučnošću, Srbi stidljivošću, smatrajući sve demimondkinje za "princeze“ i željom da se provedu, a da što manje košta. Italijani su bili najotmeniji." ${ }^{67}$ Drugi oficir, Marković, navodi: „Kvalifikacija vojski od našeg vojnika: na prvom mestu Srbi i Rusi, drugi Englezi, treći Francuzi, četvrti Italijani, Grci i Rumuni." ${ }^{\text {} 68}$

Kontakt sa francuskom vojskom uticao je na promene mnogih navika i ponašanja unutar Srpske vojske. Iz većine sačuvanih izjava srpskih vojnika uočljivo je da je pod francuskim uticajem, ili bolje reći pritiskom, prestala praksa batinanja vojnika kao disciplinska mera na Solunskom frontu. U Srpskoj vojsci oficir je do tada mogao da zbog prestupa ili disciplinske greške naredi da se vojniku „lupe batine“. Jedan kaplar 22. pešadijskog puka seća se da je bio „dežurni tog dana kada je stigla takva naredba“ od vrhovnog komandanta Savezničkih snaga generala Saraja. Pročitavši naredbu, kaplar je prokomentarisao na svoj način: „E rek'o gospodo oficiri, eve vi ga sad!“. ${ }^{69}$ Prekid ove prakse dobro je upamćen u svesti vojnika i gotovo svi ga ističu: „A pre su nas tukli ko volove. Ali još na Krfu Francuzi zakratili boj... Ne smeš da dirneš vojnika. A kad komanduješ, samo na pet koraka možeš da mu priđeš. Tako i ostalo. O, vojnik, gospodin!... Svaka čast Francuzima..." ${ }^{70}$

Sa druge strane, neke navike i praksa francuske vojske su prenete Srpskoj vojsci na Solunskom frontu. Uvedeno je davanje vina vojnicima uz ručak („Ono nema svaki dan, nego zna se, ima određeno: četvrtak, nedelja, i kad je praznik)“. Uz vino dobijane su i „francuske“ cigarete. ${ }^{71}$ Obični vojnici su dobro uočavali razlike između svojih i francuskih oficira: „Njin oficir skupi vojnike ukrug pa im priča nešto, priča, priča, pa kad završi, on izvadi kutiju cigara od sto komada pa zađe redom, sve posluži vojnike“. ${ }^{72}$

Posebna novost za srpskog vojnika bili su pripadnici francuske vojske koji su poticali iz afričkih ili azijskih kolonija. Najveći deo srpskih vojnika i oficira do tada nije susreo ljude druge rase i boje kože. O tome su upečatljivo svedočili: „Ja sam tu prvi put vido crnce. Crn ko naša trešnja crnica. Oni govore francuskim jezikom". Dvojica mladih vojnika Šumadijske divizije na brodu kada vide ložača u strahu beže na palubu: „Tu smo

${ }^{67}$ Isto, 234.

${ }^{68}$ Golgota i vaskrs Srbije 1915-1918, 528.

${ }^{69}$ Iskaz Živote Pantića, u: Tri sile pritisle Srbijicu, 153.

${ }^{70}$ Iskaz Dragoljuba Radojkovića, u: Srbijico, dušo gorka - priče solunaca, 91-92; Iskaz Mijaila Rakića, u: Srbijico, dušo gorka - priče solunaca, 106.

${ }^{71}$ Iskaz Dragoljuba Radojkovića, u: Srbijico, dušo gorka - priče solunaca, 92-93.

${ }^{72}$ Iskaz Dragoljuba Mijatovića, u: Srbijico, dušo gorka - priče solunaca, 45. 
prvi put videli crnca. Kud je crnac, još go! I mi beži gore“733. U bugarskoj vojsci susreti sa takvim vojnicima izazivaju isti efekat: „Našite voinici, kad zalovil prvija čeren plennik, pomislili, če e bojadisan, i za užas na gorkija negr, dlgo go trkali do krv, s keremida, da iztrkat černata boja“" ${ }^{74}$

U situacijama kada su oko njih francuske trupe Srbi prave razliku pa Francuzima zovu i „crnce i arape“ koje viđaju u pešadiji oko sebe, odvajajući ih od „pravih" Francuza, koje su recimo viđali u artiljeriji. ${ }^{75}$ Srpski vojnik nije mnogo razlikovao kolonijalne vojnike (navodeći bez razlike: „puk crnaca-arapa“), ali im je priznavao borbene kvalitete. „Ratnici su bili opasniji od nas. Koga zarobe, oni to pobiju. Oni išli napred, mi za njima." 76

Bliskost na linijama fronta iskovala je ratno srpsko-francusko drugarstvo koje je posebno bilo na ceni: „Francuzi su dobri drugovi“. ${ }^{77}$ Osećaj zahvalnosti, a potom i ratnog drugarstva ostao je neizbrisiv kod većine vojnika-solunaca. „O Francuzima ja i danas, i posle mene, i posle mojeg trećeg naraštaja, kažem: neka pozdravljaju Francusku-majku. Život su nam onda ljudi spasli. “78 Kako jedan od njih prostodušno sumira: „Družili smo se sa Francuzima. Voleli smo Francuze i oni su voleli nas“. ${ }^{79}$

\section{Slobodno vreme i odlazak u Solun}

Srpski vojnici su posle izvesnog vremena na frontu počeli da prilagođavaju ambijent svom dugotrajnom boravku. O tome svedoči i Arčibald Rajs u svom dnevniku, sredinom maja 1918: „Svuda gde su bujne kiše ostavile malo plodna zemljišta po stenama, on stvara mali vrt, zaliva ga brižljivo vodom sa izvora, svežom vodom sa često vrlo dalekog izvora. Crni luk, planinsko cveće, obrazuju skromni i lepi vrtić koji ga potseća na voćnjake, vinograde i sela koje dana beru i uživaju drugi. “" ${ }^{80}$ Instinkt seljaka nadmašio je ratnika. Deo vojnika je od dolaska na prve linije fronta počeo da sakuplja semenje od voća i povrća koje je raslo u blizini. „Nadali se da ćemo brzo u Srbiju, pune im vojničke torbe bile kesica i semenije. Ali rat se produžio, iduće godine oni bacaj staro i ostavljaj novo seme. Doneli neki u Srbiju raznog semena, čak i seme duvana. ${ }^{* 81}$

\footnotetext{
${ }^{73}$ Iskaz Branka Čolića, u: Srbijico, dušo gorka - priče solunaca, 269.

${ }^{74}$ Stefan Canev, Blgarski hroniki, tom 3 1878-1943, Trud, Sofija 2008, 356.

${ }^{75}$ Iskaz Milutina Ristića, u: Srbijico, dušo gorka-priče solunaca, 130.

${ }^{76}$ Iskaz Milana Gajića, u: Tri sile pritisle Srbijicu, 127.

${ }^{77}$ Iskaz Desimira Milenovića, u: Srbijico, dušo gorka - priče solunaca, 243.

${ }^{78}$ Iskaz Svetozara Andrića, u: Tri sile pritisle Srbijicu, 108.

${ }^{79}$ Iskaz Mijaila Rakića, u: Srbijico, dušo gorka - priče solunaca, 108.

${ }^{80}$ D. Vasić, $n$. d., 57.

${ }^{81}$ Iskaz Dragiše Pavlovića, u: Srbijico, dušo gorka - priče solunaca, 31.
} 
Vojnici su u slobodno vreme počeli da se bave pojedinim zanimanjima (današnjim rečnikom: hobijima). „U svome slobodnom vremenu, on je radio ručne radove i jedinstveno dovitljiv on je iznenađivao svojim zdravim duhom i svojim izumima." Čak je od radova koji su se mogli doneti sa linije fronta priređena izložba u Solunu. Za izradu ovakvih predmeta vojnici su koristili materijal „od čaura, kuršuma, parčeta od granata, čuturica, parčeta polomljenih puščanih cevi, od aluminijuma, mesinga, gvožđa, raznih metalnih legura... Od aluminijuma su izrađene duvanske kutije, upaljači kutije za palidrvca, čaše raznih vrsta, lepeze, „piksle“ za palidrvca. Sve je to po izgledu vrlo skromno ali velikim delom i sasvim ukusno, naročito pojedine lepo izgravirane čašice. Od mesinga i od kombinacija raznih metalnih polomljenih delova iz naoružanja ima najviše predmeta. To su kutije za palidrvca i duvan, mastionice, svetnjaci, čaše, vaze, lampe, krigle, pljoske." (navode se dalje predmeti od kože, drveta, minijature buradi, predmeti iz pletarstva). „Naročitu grupu predmeta činili su muzički instrumenti, violine, tambure, dvojnice, svirale, sve izrađene vrlo lepo." Zatim tri minijature: razboj, volovska kola sa išaranim kanatama i čeze „na kojima stoji natpis Spomen na Mačvu. Sve to ukupno daje utisak nečega našeg diskretnog, nostalgičnog, dirljivog“. „I pored mnogih predmeta gotovo primitivne izrade, on je ovim pokazao da, i kraj svih muka i nevolja, u njemu još uvek živi krepak duh i zdrava misao" - bio je zaključak o ovom rovovskom stvaralaštvu. $^{82}$

U slobodnom vremenu, vojska je znala da zaigra kolo uz muziku koju bi zasvirao neko od vojnika na sviralama. Ponekad bi se kolo povelo uz vojnu muziku - svirače, pronađene u pozadni. Vojnici koji su dobro pevali posebno bi pamćeni jer su melodijom oživljavali sećanje na dom. „Imali smo smenu, po nedelju dana siđemo, imalo jedno mesto, Katunac se zvalo. Tu je bio ko neki zaklon od neprijatelja. Tu smo mi prali rublje ili u pozorište išli. Igrali glumci. Napravljeno k'o pozornica... mi smo sedeli na travi... Glumci sve muškarci. Dolazila je tu vojna muzika, svirala... to je bilo jedno dva kilometra od linije, ali je takav zaklon bio da niko nije znao šta se dešava dole. ${ }^{83}$ Vojnik iz Moravske divizije svedoči: „Oni su se trudili da nas razonode. Jer čim se osami vojnik, samo misli: kad ću da vidim majku, sestru, braću...". ${ }^{84}$ O srpskom vojničkom pozorištu na frontu aprila 1918, detaljno je i sa puno hvale pisao dr Arčibald Rajs. ${ }^{85}$

Korisna zanimanja u slobodnom vremenu, uz nešto kocke i alkohola, bile su zabave na linijama fronta i njegove pozadine. Van toga za razo-

\footnotetext{
${ }^{82}$ D. Vasić, $n$. d., 56-57.

${ }^{83}$ Iskaz Aleksandra Jankovića, u: Srbijico, dušo gorka - priče solunaca, 233.

${ }^{84}$ Iskaz Svetozara Andrića, u: Tri sile pritisle Srbijicu, 109.

${ }^{85}$ Golgota i vaskrs Srbije 1915-1918, 699-701.
} 
nodu se išlo u Solun, koji je bio mesto odmora i povremenog provoda. "Zabavni život" neodoljivo je privlačio pre svega oficire srpske vojske, ali i podoficire i vojnike, sav taj svet u mladićkom uzrastu željan novih iskustava i opuštanja od strahota fronta.

Kako piše Stanislav Krakov, ovaj grad je postao metropola jedne armije, sakupljene sa četiri kontinenta od svih rasa, religija i nacija. ${ }^{86}$ A Deroko pojašnjava: Solun je bio „tada jedan fantastičan centar svega i svačega. Bio je pozadina, živa i bučna, daleka od fronta... Tu su bili štabovi, bolnice, glavno snabdevanje, a pored svega: zabava." ${ }^{87}$

„Samo, on (Solun) je sa svim svojim privlačnostima bio nama teško dostupan. Trebala je naročita dozvola koja se teško dobijala, i uz sasvim izuzetan razlog. Pa i sa tom dozvolom, noćni barovi i zabave, bar nama nižima u vojsci, bili su zabranjeni. Patrole su krstarile svuda i proveravale dozvole i papire." ${ }^{88}$ Vojnici koji su dobili dozvole su se nekoliko sati spuštali do najbliže stanice, a potom se hvatao voz do Soluna. „U Solunu si mogao da kupiš šta 'oćeš i da se provedeš lepo. Moglo je da se uđe u kafanu, imala jedna velika kafana, zvala se Olimpus. Mog'o si da pojedeš sve šta 'oćeš, i da ručaš... u Solunu je svačega imalo". ${ }^{89}$

Oficiri su lakše posećivali Solun. U zapisima nekolicine oficira i podoficira kao posebno mesto zabave figurira kafana „Tur Blanš“. Jakov Ljotić navodi: „Skoro svako veče išao sam u „Tur Blanš“, gde sam imao veliki broj poznanika, kako među našim, tako i među stranim oficirima. Glavni gosti „Tur Blanša“ bili su francuski i engleski oficiri, zatim Rusi i Srbi."90 Stanislav Krakov piše da su on i njegove kolege oficiri ostavljali francuske uniforme i preodevali se u delove engleske uniforme, koja se mogla kupiti zajedno sa tropskim šlemom i drugim detaljima. Izgled što više nalik na britanskog oficira bio je „za svakog od nas najveći izraz elegancije.“"

Oko odlaska u javne kuće postoje oprečna sećanja. U oficirskim krugovima „odlazak u Solun“ je bio uobičajena stvar. Za oficire bilo je, kako piše Krakov, „stotine zatvorenih kuća“, gde se isključivalo „učešće ulice u intimnim susretima“. ${ }^{92}$ Pojedini vojnici takođe su išli „u Solun zbog ženski“. Neki su to i slobodnije zvali: „Brale, ajdemo u Solun na kurvanje." gradu su vojničke javne kuće bile locirane u Vardarskoj ulici. Kako svedoči S. Krakov, u kvartu „najniže i najbestidnije prostitucije" u kojem je bila ova

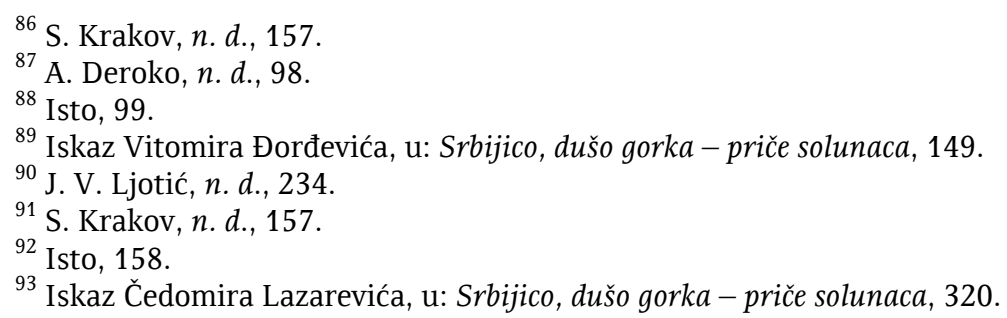


ulica, dolazili su samo vojnici iz kolonija, a ovde nije primećivao vojnike bele rase. ${ }^{94}$ Pojedini srpski vojnici, međutim, kasnije su se sećali ove ulice: „Jooj, cela Vardarska ulica u Solunu. Na kraj Soluna. Imalo kurve koliko 'oćeš. Grkinje, najlepše Grkinje. Možeš na zadnjici crtak da joj otkoveš... Išla vojska, išli i mi, ali ređe... pa kad se vojnik vrati iz pozadine, ili iz Soluna, pitaju ga: Jesi l' bio u vardarskoj diviziji? Oficiri nisu davali da idemo tamo. Vodili računa. Nego koj' umakne, ovako na dozvolu. “95

Posebna prilika za ovakvu avanturu bio je boravak u nekoj od vojnih bolnica u Solunu, kada je moglo da se lako dođe do takvih mesta. Drugi su se snalazili u blizini fronta: „Iskradali smo se noćom, išli po selu kod Grkinja““ ${ }^{96}$

U Bizerti se takođe odlazilo u javne kuće u slobodnom vremenu. U nekima od njih bile su samo Francuskinje („Tamo imao kupleraj. Francuskinje od 15 do 30 godina. Uđeš, dva franka metalna ubaciš. Svaka ženska imala numeru. Ti ubaciš paru, ona ide otud. Ako ti se svidi: idi. Ako ne, ti ponovo ubaci paru“), odnosno one koje su srpski vojnici zvali „arapski kupleraj“ („Ijaoj! Arapkinje, mulatkinje. Ijaoj! Unutra ovako krug, one okolo igraju. Ima jedan u krugu što svira u neke zurle, one skoro gole igraju. A mi sedimo, biramo. Samo daj franak“.. $)^{97}$

U mnogim sećanjima ili izjavama ukazuje se da su vojnici bili svesni da nije dobro upuštati se u ovakve avanture. Pojedini vojnici govore da im je od starijih preporučeno „za vreme rata ne pipaj u žensku... Ženama nisam prilazio, meni su to stariji kazali i ja sam to vezao za ozbiljnost". ${ }^{98}$ Slično beleže i pojedini oficiri kao Dimitrije Ljotić, tada potporučnik u 5 . puku: „Front je bio u planinama. Na frontu Drinske divizije nigde naselja. Kod Srpske vojske inače, za vreme operacija, vlada najveća moguća čednost, koja dolazi od narodnog verovanja da čovek koji nije čedan, koji ide za ženama, mora platiti glavom. Na frontu naše divizije je to bilo potencirano potpunim odsustvom svakog naselja. Zapazili smo da ljudima to uzdržavanje nije ne samo škodilo, već ih činilo uravnoteženijim i vedrijim. “99

\section{Predrasude}

Za razliku od nekih savezničkih vojski koje su imale žene u svom aktivnom - doduše pomoćnom sastavu, u Srpskoj vojsci su bile samo dve

${ }^{94}$ S. Krakov, n. d., 158

${ }^{95}$ Iskaz Vitomira Đorđevića, u: Srbijico, dušo gorka - priče solunaca, 152.

${ }^{96}$ Iskaz Dragiše Pavlovića, u: Srbijico, dušo gorka - priče solunaca, 31; Iskaz Petronija Markovića, u: Srbijico, dušo gorka-priče solunaca, 77.

${ }^{97}$ Iskaz Ljubomira Pavlovića, u: Tri sile pritisle Srbijicu, 274-275.

${ }^{98}$ Iskaz Živote Pantića, u: Tri sile pritisle Srbijicu, 155-156.

${ }^{99}$ Dimitrije V. Ljotić, Odabrana dela 1. knjiga, Minhen 1981, 310. 
žene u aktivnoj službi. Obe su bile borci i to kod 2. pešadijskog puka: Flora Sands i Milunka Savić. Engleskinja Flora je došla u puk 1915, prateći poručnika Jovića, koji je kasnije nastradao. Ona je od običnog vojnika napredovala sve do potporučnika, bila ranjena i odlikovana Karađorđevom zvezdom. „Učestvovala je u svima borbama i u svakoj borbi se sjajno držala“, i kao borac kako piše J. Ljotić „zaslužila i čin i odlikovanja“. Drugi puk je mogao da se „ponosi ovom Engleskinjom i njene zasluge ne bi smele nikad da budu zaboravljene“. Milunka Savić je u puk stigla iste, 1915. godine i napredovala je od običnog vojnika do podnarednika, bila ranjavana i odlikovana. „Nije se razlikovala od drugih vojnika, i mogu reći, da vojnici u njoj nisu gledali devojku. Bilo je šale i smeha sa njom, ali zaista za sve vreme dok je bila u četi, nije se moglo ništa reći rđavo ili neugodno primetiti ili čuti. Možda se to ima pripisati i čednosti Moravaca za vreme rata, kao i ukorenjenom verovanju da se za vreme rata mora biti čedan."100

Za razliku od srpske, u savezničkim vojskama bio je angažovan veći broj žena. Najviše srpskih vojnika susretalo se sa ženama u bolnicama, ali bilo je i onih koje su radile kao šoferi ili u drugim pomoćnom službama. Obični vojnici su se mahom stideli u susretima sa „stranim“ ženama. „Tek ugledasmo: dolazi otud jedna mlada engleska doktorica. Mi se sklonismo iza stene. Ona dođe sasvim blizu, pogleda malo okolo i poče da se svlači. Svuče sve sa sebe. Gola! Potpuno gola siđe do vode, pljuska se malo, pljuska, pa zađe u vodu i zapliva... Vide i ona nas, ali ništa ona. “101

Stid pred „nepoznatim ženama“ se posebno uočavao u bolnicama, gde je bio veliki broj medicinskih sestara i doktorki, koje su za srpske vojnike bile novost. Od dolaska u bolnicu, gde je bilo obavezno kupanje uz prisustvo medicinskih sestara, pa preko neobičnog merenja temperature do samog lečenja i oporavka u bolnici.

Evo kako su to videli srpski vojnici: „Ja uš'o u kupatilo i bolničarka ušla sa mnom. Nosi preobuku. I onda pokazuje mi da skinem odelo. Kako mogu da skinem odelo pred nepoznatom ženom?! Ona meni pokazuje da skinem, a ja njoj pokazujem da ona iziđe napolje pa ću da se skinem. Ne, moram da se svučem pred njom! Kako da se svučem... Ona dreknu na mene..." Potom u bolničkoj sobi, sestra prepričava najstarijoj sestri ovaj događaj: „One su se smejale, a ja sam crveneo od stida," priča svoje muke jedan srpski vojnik. ${ }^{102}$

Merenje temperature $u$ francuskim bolnicama bilo je posebno neprijatno za srpske vojnike i oficire. „Kod Francuza se meri temperatura zavlačenjem termometra u čmar. Naši ljudi to nisu mogli da shvate, smatrajući

${ }^{100}$ J. V. Ljotić, n. d., 214-215, 225-228.

${ }^{101}$ Iskaz Dragoljuba Mijatovića, u: Srbijico, dušo gorka - priče solunaca, 45.

${ }^{102}$ Iskaz Svetislava Kovačevića, u: Srbijico, dušo gorka - priče solunaca, 309. 
to za ružno i sramotno. Termometre je delila jedna sestra-kaluđerica, i svakom bolesniku mimikom pokazivala gde i kako da stavi termometar. Mi smo svi to sami radili, ispod pokrivača, ali jedan kapetan, to nikako nije hteo i mogao. On je merio temperaturu ispod pazuha, ali sestra na to nije nikako pristajala. Na kraju, ona je naredila kapetanu da legne potrbuške, a ona mu je sama stavila termometar. Siromah kapetan, menjao je boju, znojio se, ali nije imao kud i morao je da se podvrgne ovoj, za njega, najtežoj operaciji. Bilo ga je stid i sramota i od sestre, i od svih nas. Sutradan, javio se da ide u komandu, iako je stvarno još uvek bio bolestan“. ${ }^{103}$

Uočljive su i pojave predrasuda nastalih iz susreta sa nepoznatim. Neke od njih bile su vezane za ishranu koju je obezbeđivala francuska vojska.

„Slična je priča bila i sa pekmezom (marmeladom). Vojnici su za doručak primali čaj i pekmez. U neko vreme počeše neki vojnici da odbijaju prijem pekmeza. Tako je počeo pekmez da preostaje, pa je onda višak razdeljivan onima koji su hteli da ga jedu. Najzad se ustanovilo šta je uzrok ovoj pojavi. Proneo se bio glas, da Francuzi u pekmez stavljaju nekakav prašak za umirenje polnog prohteva, ali da njegovo dejstvo malo po malo i pri dužoj upotrebi ostaje stalno... Nekako smo uspeli da razbijemo ovu zabludu. Kad smo već kod jela, onda da vam spomenem i slučaj sa zečetinom. Jedno vreme primali smo zečje meso, ali to se brzo moralo da prekine. Bilo je to meso od pitomog zeca. Iako su zečevi dobijani u neodranom stanju, pa su ih drali kuvari, ipak ih vojnici nisu rado gledali. Govorili su da su to mačke, a oni mačke ne jedu. Neke smo razuverili ali najupornije nismo. Oni su govorili da ovo što mi dobijamo nisu mačke, ali nisu ni zečevi, nego da su mešanci od mačaka i zečice, dakle nešto kao mačkozec" ${ }^{104}$

I pored stida i straha od nepoznatog, korisne navike i praksa su brzo usvajani. Posebno ono što je vojniku omogućavalo komotnost, sitost, osećaj nemanja oskudice u bilo čemu. Jedan oficir zapaža uticaj noviteta na svoje vojnike: „Ljudi su bili dobro hranjeni, pa relativno dobro (a s obzirom na zdrav planinski zrak) i zdravo smešteni, zatim vrlo dobro odeveni i obuveni. “105 Drugi oficir primećuje reakciju svojih vojnika: „Sad se bolje hrane i odevaju neko ikada kod svojih kuća. Vajkaju se u šali: „kako ću kod kuće bez kafe, čaja, supe, vina biskvita...". ${ }^{106}$

O izuzetnom kvalitetu srpskog vojnika na Solunskom frontu upadljivo svedoče zapisi tadašnjeg potporučnika Dimitrija Ljotića, vodnika u 5 . puku: „Posmatrao sam život na frontu. Bolji ljudi se teško mogu naći zajedno $u$ tolikom broju. Posle albanskog povlačenja ostalo je zaista u vojsci ono

\footnotetext{
103 J. V. Ljotić, $n$. d., 171.

${ }^{104}$ Golgota i vaskrs Srbije 1915-1918, 688.

105 D. V. Ljotić, Odabrana dela 1. knjiga, 311.

${ }^{106}$ Golgota i vaskrs Srbije 1915-1918, 528.
} 
što je imalo naročitu svest o dužnosti prema zemlji... Preko Albanije (je) prešao i na Solunski front došao zaista najbolji mogući odbir, jer je birala Albanska Golgota prvo, a posle se zabušant i kukavica mučio na svaki način da se domogne Italije, Francuske i Švajcarske, ili da ostane na Krfu, ili na posletku bar da ostane u Solunu. “107

Bojan B. Dimitrijević

SERBIAN SOLDIER ON THE MACEDONIAN FRONT 1916-1918

\section{Summary}

In the recent period, when the $100^{\text {th }}$ Anniversary of the Great War actualized the research of the subjects related to this war, the issue of the soldier's life on the front and his daily routine, behavior, different attitudes, fears and prejudices, remained out of the research. The Serbian military primarily sources from the war also do not pay too much attention to this subject. The article provides framework for an overview of the social life of the Serbian soldier on the Macedonian Front 1916-1918. Mostly it is related to soldier's non-combat activities while on the front and away from Homeland. The article also analyses the common soldier's attitudes toward the Allies on the front. It is based on collected oral testimonies, gathered in Serbia in 1980ties among the veterans, as well as from the memoir literature.

${ }^{107}$ D. V. Ljotić, Odabrana dela 1. knjiga, 310. 